\title{
Katarzyna Pawlak
}

(Uniwersytet Medyczny w Łodzi

Zakład Patologii Społecznych)

\section{Społeczny obraz chorego na AIDS w perspektywie historycznej}

Większość schorzeń budzi wśród osób zdrowych współczucie i chęć niesienia pomocy. Opieka nad chorym wynika $z$ emocjonalnych więzi łaczacych ludzi. Jest też przywilejem przypisanym roli społecznej chorego. Nie zawsze jednak tak się dzieje. Choroby szczególnie niebezpieczne, zakaźne, wstydliwe, budzace lęk i odrazę, skazują nierzadko osoby nimi dotknięte na samotność, a niekiedy wręcz ostracyzm społeczny. Jedną z nich jest zespół nabytego niedoboru odporności (AIDS).

\section{Piętno życia z AIDS}

Schorzenia dla jednostek nimi dotkniętych stanowią rodzaj usprawiedliwienia z niewywiązywania się z dotychczasowych ról i zadań społecznych. Talcott Parsons analizując rolę chorego zwrócił uwage na trzy elementy, które ją opisuja. Po pierwsze chory nie jest odpowiedzialny za swój stan, który wynika z czynników niezależnych od zachowania i decyzji podjętych przez jednostke. Prowadzi to do stwierdzenia, że „osoba chora ma pewne prawa i przywileje, w tym prawo do zwolnienia z codziennych obowiązków (...), ról i zachowań, co do których w innych okolicznościach musi się stosować" (Giddens 2010:181). W końcu po trzecie, chory ma obowiązek szukania fachowej pomocy, nie tylko dla potwierdzenia swojego stanu, ale także by pracować nad powrotem do zdrowia. Koncepcja Parsonsa nie uwzględnia jednak problemu zróżnicowania schorzeń i związanej z tym reakcji otoczenia pacjenta. Eliot Freidson biorac pod uwage ten czynnik zaprezentował trzy wersje roli chorego: warunkowa, bezwarunkowa prawomocna i nieprawomocna. Pierwsza dotyczy osób, co do których rokowania sa pomyślne, a schorzenie jest tylko stanem przejściowym. Od takich chorych oczekuje się powrotu 
do zdrowia i zawieszonych tymczasowo ról oraz zadań. Bezwarunkowo prawomocna rola chorego związana jest ze schorzeniami nieuleczalnymi. Otoczenie w pełni usprawiedliwia i zwalnia takie jednostki z większości obowiązków. Wydawałoby się, biorąc pod uwagę charakterystykę schorzenia, że chorzy na AIDS powinni klasyfikować się właśnie do tej grupy. Jednakże w przypadku tej choroby jej nieuleczalność przysłonięta jest innymi cechami (zwłaszcza przekonaniem otoczenia o odpowiedzialności chorego za swój stan zdrowia), które powodują, że zakażony wirusem HIV otrzymuje nieprawomocna rolę chorego i tym samym odmawia mu się dodatkowych praw oraz przywilejów. Dzieje się tak wówczas, kiedy jednostka cierpi na schorzenie lub przypadłość piętnowana przez innych, tj. chorobe najczęściej niezwykle zakaźna lub wstydliwą.

„Słowo piętno (stigma) odnosi się współcześnie do każdego stanu, atrybutu lub cechy, która znaczy jednostke jako nie do zaakceptowania pod względem kulturowym lub jako „gorsza”. Określenia co jest, a co nie jest do zaakceptowania sa zmienne i niejednakowe w różnych epokach historycznych i kulturach" (Sokołowska 1986:211). Dotyczy to nie tylko zachowań przestępczych, ale również jednostek chorobowych budzących szczególny lęk lub odrazę w szerszej świadomości społecznej. Piętno opiera się głównie na stereotypach i błędnym lub tylko częściowym rozumieniu sytuacji chorego. Wynika więc najczęściej z niewystarczajacej wiedzy o schorzeniu, jej drogach zakażenia, czy profilaktyce, jak również skutecznej metodzie leczenia. Etykieta przypisana choremu nadaje mu nowa, dewiacyjna pozycję społeczna lub tożsamość przekreślając dotychczasowa. Co więcej dla osoby, „która otrzymała etykietę, niefortunna konsekwencja jest fakt, że piętno zaczyna dominować w postrzeganiu tej osoby przez innych. Kimkolwiek by ona nie była (np. ojcem, rzemieślnikiem itp.) traktuje się ją przede wszystkim jak dewianta" (Sokołowska 1986:213), zaś ,jego dotychczasowa tożsamość czerpana z poczucia przynależności do społeczeństwa, różnych grup w jego ramach, zajmowania różnych pozycji i pełnienia różnych ról ulega destrukcji. Pojawia się w to miejsce tożsamość człowieka marginesu, wygnańca, outsidera" (Sztompka 2002:412). Etykieta, która zostaje nadana odzwierciedla się w jaźni chorego jako autodefinicja odrzuconego, co prowadzi do spadku samooceny, poczucia odrzucenia, bycia gorszym czy wręcz bezsensu dalszej egzystencji.

Etykieta „chory na AIDS” jest szczególnie dotkliwa. Nierzadko przekłada się na społeczny ostracyzm, izolację, zepchnięcie na margines. Wysoki stopień stygmatyzacji osób zakażonych wirusem HIV ma swoja przyczynę w wielu czynnikach. Można je podzielić na te o charakterze medycznym, wynikajace ze specyfiki choroby oraz przyczyny społeczno-kulturowe (patrz tabela 1). Wśród tych pierwszych należy wymienić: 
długi okres utajnienia choroby, zaś pod jej koniec widoczne objawy i towarzyszący im ból, globalny zasięg AIDS, oraz ciągle brak skutecznej metody wyleczenia. Z kolei do przyczyn społeczno-kulturowych możemy zaliczyć: niedostateczny poziom wiedzy na temat choroby, jej dróg zakażenia i profilaktyki, historyczne i kulturowe naleciałości związane m.in. z utożsamianiem AIDS z wybranymi, już napiętnowanymi społecznie jednostkami, a także obwinianie osób chorych za ich stan i dużą zależność od innych zwłaszcza na ostatnim etapie schorzenia.

Tabela 1. Przyczyny stygmatyzacji chorych na AIDS

\begin{tabular}{|l|l|}
\hline \multicolumn{1}{|c|}{ Przyczyny medyczne } & \multicolumn{1}{c|}{ Przyczyny społeczno-kulturowe } \\
\hline długi okres utajnienia choroby & niedostateczny poziom wiedzy \\
\hline widoczne objawy pod koniec choroby & zależność chorego od innych \\
\hline choroba śmiertelna & $\begin{array}{l}\text { przypisywanie choroby grupom } \\
\text { już napiętnowanym społecznie }\end{array}$ \\
\hline globalny zasięg & historyczne i kulturowe naleciałości \\
\hline Ból & obwinianie osób chorych za ich stan \\
\hline
\end{tabular}

Źródło: opracowanie własne.

\section{Globalny zasięg}

W 1978 r. pojawiły się w USA pierwsze sygnały o nowej, dotąd niezidentyfikowanej jednostce chorobowej (Kmiecik-Baran 1995:47), której towarzyszyły takie schorzenia, jak pneumocystozowe zapalenie płuc oraz mięsak Kaposiego. Współczesne modele teoretyczne sugeruja jednak, że nie Ameryka Północna była miejscem pierwszego zetknięcia się człowieka z wirusem HIV, a kontynent afrykański. Co więcej ze względu na długi okres inkubacji zakłada się, że choroba rozwijała się w USA na długo przed 1978 rokiem. Szybkość, z jaką wirus się rozprzestrzenia czyni go jednym z najniebezpieczniejszych zagrożeń zdrowia społeczności na całym świecie. Epidemia zakażenia HIV charakteryzuje się bardzo dużym dynamizmem i szybkością. Wirus dotarł już na każdy kontynent. Jeszcze w 1992 r. sądzono, że na świecie jest 12,9 mln nosicieli tego wirusa. Obecnie szacuje się, że żyje około 34 mln osób zakażonych wirusem HIV. Większość z nich to osoby dorosłe (ponad $30 \mathrm{mln}$ ). Choroba nie odróżnia płci, choć zgodnie z danymi Światowej Organizacji Zdrowia z 2011 r. choroba dotyczy 2 mln więcej kobiet niż mężczyzn. Co roku odnotowuje się około 2,5 mln nowych zakażeń (WHO 2011). Obszarem charakteryzującym się największym zagrożeniem HIV pozostaje Afryka, zwłaszcza południowa (patrz tabela 2). Odsetek osób 
zarażonych wirusem HIV waha się tam w zależności od kraju od około $1 \mathrm{mln}$ do ponad $5 \mathrm{mln}$, co stanowi w niektórych przypadkach nawet $25 \%$ całej populacji tych państw.

Tabela 2. Odsetek osób zarażonych wirusem HIV w wybranych krajach Afryki w latach 1990 i 2011

\begin{tabular}{|l|c|r|}
\hline \multicolumn{1}{|c|}{ Kraj } & $\mathbf{1 9 9 0}$ & $\mathbf{2 0 1 1}$ \\
\hline Zimbabwe & 720000 & 1200000 \\
\hline Uganda & 1200000 & 1400000 \\
\hline Tanzania & 660000 & 1600000 \\
\hline Zambia & 560000 & 970000 \\
\hline Malawi & 360000 & 910000 \\
\hline Mozambik & 24000 & 1400000 \\
\hline Kenia & 280000 & 1600000 \\
\hline Nigeria & 230000 & 3400000 \\
\hline Etiopia & 330000 & 790000 \\
\hline
\end{tabular}

Źródło: opracowane na podstawie UNAIDS (2011): www.unaids.org/en/dataanalysis/datatools/aidsinfo.

Choć kontynent afrykański jest najbardziej narażony na działanie wirusa HIV, problem ma charakter globalny. Odsetek osób zarażonych na przełomie ostatnich 20 lat wzrósł niemal we wszystkich krajach. Znaczna ich część zamieszkuje USA (1 300 000), Chiny (780 000), Rosję (730 000), Tajlandię (490 000) i Indonezję (380 000). Biorąc zaś pod uwage procent, jaki chorzy stanowia w populacji danego kraju trzeba w tym miejscu wymienić także Europę wschodnią zwłaszcza Ukrainę, państwa nadbałtyckie - Łotwę i Estonię, jak również Portugalię.

\section{Przebieg choroby (od utajnienia do ujawnienia)}

HIV (human immunodeficiency virus) jest wirusem powodujacym upośledzenie odporności. Przedostając się do organizmu atakuje limfocyty pomocnicze T (tj. komórki CD4+), powodując ich wyraźny liczebny spadek. W konsekwencji prowadzi do osłabienia chorego i utraty odporności, a tym samym podatności na różnego rodzaju schorzenia. HIV rozwija sie praktycznie bezobjawowo. Po dostaniu się do organizmu człowieka zaczyna się intensywnie namnażać, powodując wyraźny i gwałtowny spadek liczby limfocytów CD4+. W konsekwencji może rozwinąc się tzw. choroba retrowirusowa, objawiająca się m.in. gorączką, powiększeniem węzłów chłonnych, bólem gardła, kaszlem, nocnymi 
potami, dusznością i biegunkami. Grypopodobne objawy często są mylnie diagnozowane, nie przypisywane działaniom HIV i tym samym lekceważone. Jednocześnie silna odpowiedź immunologiczna organizmu ludzkiego powoduje chwilowa rekompensate strat w limfocytach CD4+ wywołanych przez wirusa i tym samym ustapienie niepokojacych sygnałów. Rozpoczyna się drugi, trwajacy nawet klika lat, etap zakażenia, który przebiega praktycznie bez żadnych objawów klinicznych. Przez ten czas nosiciel HIV może nie zdawać sobie sprawy z zakażenia i postępującej w jego organizmie choroby. Na tym etapie niewidoczność schorzenia zmniejsza stopień stygmatyzacji osób z HIV. Nie ma wyraźnego i czytelnego dla otoczenia znaku ich odmienności. Jednakże to właśnie ta cecha choroby, zwłaszcza wśród osób o niewielkiej wiedzy dotyczacej jej dróg zakażeń i profilaktyki, budzi strach. Z jednej strony maja świadomość istnienia jednostek zakażonych HIV, z drugiej nie moga w żaden sposób (o ile taka osoba się nie przyzna) jej odróżnić.

Bezobjawowy okres nie oznacza zatrzymania choroby. Wirus HIV przemieszczając się krwiobiegiem namnaża się tworzac pewien rodzaj rezerwuaru w ciele zakażonej osoby. Następuje systematyczne niszczenie limfocytów CD4+ (spadek poniżej 200 limfocytów CD4+/ $\mathrm{mm}^{3} \mathrm{krwi}$ ), których to braki organizm nie jest w stanie uzupełniać. W konsekwencji dochodzi do uszkodzenia układu immunologicznego i rozwinięcia cię pełnoobjawowego AIDS.

Jest to moment ujawnienia się choroby na zewnattrz. Uszkodzony układ odpornościowy prowadzi do pojawienia się infekcji oportunistycznych. Schorzenia towarzyszące pełnoobjawowemu AIDS jak: biegunki, kandydoza płuc lub oskrzeli oraz przełyku, inwazyjny rak szyjki macicy, cytomegalowirusowe zapalenie siatkówki prowadzące do utraty wzro$\mathrm{ku}$, encefalopatia, przewlekłe i ciężkie zakażenie wirusem opryszczki, mięsak Kaposiego, chłoniaki, w tym chłoniak Burkitta czy pierwotny chłoniak mózgu, rozsiane lub pozapłucne zakażenia prątkami, gruźlica skutkuja olbrzymim wyniszczeniem organizmu. Gwałtownej zmianie ulga fizyczność chorego m.in. poprzez spadek masy ciała, zmiany skórne, utratę włosów itp. Rozwój AIDS sprawia, że chory coraz częściej potrzebuje pomocy innych w zwykłych czynnościach dnia codziennego. Traci swoją niezależność i autonomię. Prowadzi to do poczucia zagubienia swojej tożsamości, sam zaś zakażony określa się jako więzień w coraz bardziej niedoskonałym, zniekształconym i niesprawnym ciele. Doświadcza bólu fizycznego. Jednocześnie towarzyszy mu lęk przed zbliżająca się śmiercia. Na tym etapie swojego schorzenia chorzy pozostaja często sami. Fizyczne oznaki AIDS naznaczają ich. Nie są w stanie dłużej ukrywać swojej choroby. Zmiany fizyczne ciała, będące wyraźną konsekwencją zakażenia, skazują chorych na ostracyzm społeczny. Z jednej 
strony jest to spowodowane lękiem przed AIDS, o którym przypominaja widoczne objawy schorzenia. Z drugiej strony kult piękna, młodości, sprawności obowiązujący $\mathrm{w}$ nowoczesnych społeczeństwach prowadzi do odrzucenia i izolacji wszystkich tych jednostek, które zaprzeczaja przyjętemu wzorcowi tj. ludzi starszych, chorych, niepełnosprawnych.

\section{Ból i śmieré}

AIDS jest zaliczana do grupy chorób, które budzą największy lęk społeczny. Nie tylko ze względu na szybkość rozprzestrzeniania się czy zasięg geograficzny. Strach przed AIDS spowodowany jest także bólem towarzyszacym chorobie zwłaszcza na jej ostatnim etapie oraz nieuleczalnościa (Skrzypek 2011:182-184). Mimo wieloletniego doświadczenia w rozpoznawaniu AIDS i wysokiego poziomu wiedzy na ten temat oraz intensywnych badań w celu znalezienia skuteczniej metody leczenia, nie udało się jak dotąd powstrzymać epidemii tej choroby. Zakażeni mają szanse nawet przez kilkanaście lat funkcjonować we względnym komforcie pod warunkiem, że choroba zostanie rozpoznana wystarczająco wcześnie, a chory będzie objęty specjalistyczną opieką lekarska. Nie zmienia to jednak faktu, że w zdecydowanej większości przypadków AIDS wcześniej czy później doprowadzi do przedwczesnej śmierci pacjenta. W $2011 \mathrm{r}$. zgodnie z danymi WHO zmarło 1,7 mln zakażonych wirusem HIV. W latach 1983-2008 25 mln zgonów było spowodowanych AIDS.

\section{Poziom wiedzy}

Poziom wiedzy na temat AIDS jest kluczowym czynnikiem w kształtowaniu społecznego obrazu osób zakażonych, dotyczy to zarówno potencjalnych dróg zakażenia, jaki profilaktyki. Światowa Organizacja Zdrowia, mając na uwadze szybkość rozprzestrzeniania się AIDS na świecie, głównie poprzez szeroko zakrojone kampanie dąży do podniesienia świadomości społeczeństw zwłaszcza w zakresie możliwości zarażenia się wirusem HIV. W ten sposób stara się z jednej strony powstrzymać epidemię choroby, z drugiej zmniejszyć problem dyskryminacji osób zakażonych. Prowadzone kampanie przynoszą różne rezultaty w zależności od regionu. Generalnie przyjmuje się, że poziom wiedzy na temat AIDS w krajach rozwiniętych jest zadawalajacy, a zdecydowana 
część tych społeczeństw potrafi w sposób bezbłędny wskazać najczęstsze drogi zakażenia wirusem. Istnieje jednak wiele obszarów, gdzie wiedza ta jest zdecydowanie niewystarczająca.

Tabela 3. Wiedza Polaków na temat dróg zakażenia

\begin{tabular}{|c|c|c|c|c|c|c|c|c|c|}
\hline \multirow{3}{*}{$\begin{array}{l}\text { W jaki sposób, Pana(i) } \\
\text { zdaniem, można } \\
\text { zarazić się wirusem } \\
\text { wywołującym AIDS? }\end{array}$} & \multicolumn{3}{|c|}{$\begin{array}{l}\text { W ten sposób } \\
\text { można sie } \\
\text { zakazić }\end{array}$} & \multicolumn{3}{|c|}{$\begin{array}{l}\text { W ten sposób } \\
\text { nie można sie } \\
\text { zakazić }\end{array}$} & \multicolumn{3}{|c|}{$\begin{array}{l}\text { Trudno } \\
\text { powiedzieć }\end{array}$} \\
\hline & 1992 & 1996 & 2001 & 1992 & 1996 & 2001 & 1992 & 1996 & 2001 \\
\hline & \multicolumn{9}{|c|}{ W procentach } \\
\hline $\begin{array}{l}\text { kontakty seksualne z osoba } \\
\text { tej samej płci }\end{array}$ & 89 & 89 & 93 & 3 & 3 & 2 & 8 & 8 & 5 \\
\hline $\begin{array}{l}\text { kontakty seksualne z osoba } \\
\text { odmiennej płci }\end{array}$ & 89 & 94 & 93 & 3 & 1 & 2 & 8 & 5 & 5 \\
\hline $\begin{array}{l}\text { narodzenie się z matki } \\
\text { zakażonej wirusem } \\
\text { wywołującym AIDS }\end{array}$ & - & 87 & 80 & - & 4 & 9 & - & 9 & 11 \\
\hline transfuzja krwi & 94 & 95 & 9 & 1 & 1 & 1 & 5 & 4 & 5 \\
\hline $\begin{array}{l}\text { korzystanie ze strzykawek } \\
\text { i sprzetu medycznego } \\
\text { wielokrotnego użytku }\end{array}$ & 93 & 94 & 95 & 2 & 2 & 2 & 5 & 4 & 3 \\
\hline ukąszenie komara & 31 & 26 & 34 & 46 & 54 & 51 & 23 & 20 & 15 \\
\hline $\begin{array}{l}\text { korzystanie z publicznej } \\
\text { toalety i łaźni }\end{array}$ & 23 & 31 & 27 & 61 & 55 & 61 & 16 & 14 & 12 \\
\hline $\begin{array}{l}\text { Korzystanie z naczyń, } \\
\text { szklanek, ręczników itp. } \\
\text { przedmiotów wspólnie } \\
\text { z osobami zakażonymi } \\
\text { wirusem }\end{array}$ & 20 & 27 & 22 & 64 & 62 & 67 & 16 & 11 & 11 \\
\hline $\begin{array}{l}\text { kodzienne kontakty z chorymi } \\
\text { na AIDS, np. w szkole, pracy, } \\
\text { w miejscu zamieszkania }\end{array}$ & 14 & 18 & 13 & 71 & 71 & 77 & 15 & 11 & 10 \\
\hline
\end{tabular}

Źródło: CBOS (2001), Spoteczeństwo wobec chorych na AIDS, Warszawa.

W wypadku polskiego społeczeństwa poinformowanie o rzeczywistych źródłach zakażenia jest oceniane w miarę wysoko (patrz tabela 3) i wiedza ta utrzymuje się na stałym poziomie. „Jednocześnie jednak ponad jedna czwarta społeczeństwa (27\%) sądzi, że można się zakazić tym wirusem korzystając z publicznych toalet i łaźni, a ponad jedna piąta (22\%) jest zdania, iż źródłem zakażenia może być wspólne z chorymi korzystanie z naczyń, ręczników i innych przedmiotów" (CBOS 2001).

Społeczeństwo dzieli również opinia o przenoszeniu wirusa HIV przez owady. Wydaje się więc, jak sugeruje Wojciechowska, że wiedza 
na temat jak można się zakazić HIV wśród Polaków jest stosunkowo wysoka. Jednakże duże niedostatki pojawiają się w drugim rodzaju wiedzy tj. jak nie można się zakazić HIV (Wojciechowska 2011:118).

Trzeba w tym miejscu zaznaczyć, że mimo dość wysokiego poziomu wiedzy Polaków o AIDS, schorzenie to zaraz po chorobie nowotworowej i serca wymieniane jest jako budzące najwięcej obawy i lęku (TNS 2012).

\section{Naleciałości historyczne i kulturowe}

Na początku lat 80. w USA coraz częściej do lekarzy zaczęli zgłaszać się młodzi, homoseksualni mężczyźni ze schorzeniami do tej pory rzadko występującymi tj. pneumocystozowym zapaleniem płuc i mięsakiem Kaposiego. Dolegliwości te przebiegały w bardzo agresywnej formie, dotąd nieodnotowanej, a u chorych stwierdzano bardzo duże niedobory odporności. Odsetek zakażonych szybko się zwiększał nie tylko w środowisku homoseksualnym, ale także narkomanów i prostytutek. Zaobserwowana w ten sposób nowa jednostka chorobowa została przypisana grupom wykluczonym i w konsekwencji nazwana GRID (Gay-Related Immune Deficiency). Wraz z rozwojem badań i podnoszeniem poziomu wiedzy na temat pojawiajacej się choroby, zmieniono nazwe z mocno stygmatyzującej na bardziej neutralna (z GRID na AIDS). Jednakże ta naleciałość historyczna ciągle w wielu środowiskach wpływa na spostrzeganie osób zakażonych. Ten stereotypowy obraz stanowi bardzo silne źródło stygmatyzacji chorych na AIDS. Nakładają się bowiem na siebie dwa rodzaje piętna. $\mathrm{Z}$ jednej strony mamy do czynienia z tzw. stygmatami pierwotnymi m.in. homoseksualizmu czy narkomanii, z drugiej stygmat choroby HIV/AIDS. Wszystkie z nich oznaczają naruszanie specyficznych norm społecznych. Tym samym moga powodować wzmocnienie poszczególnych stygmatów i różne przejawy dyskryminacji chorych. Tymczasem większość zakażeń HIV na świecie następuje w wyniku kontaktów h1eteroseksualnych (około 70\%), a tylko około 15\% poprzez homoseksualne (Gładysz 2007:11-13).

Trzeba jednak w tym miejscu zwrócić uwage na fakt, że „choć charakterystyka biologiczna HIV nie zmienia się zależnie od kraju czy grupy społecznej, to jednak przebieg epidemii w każdym kraju zależy od warunków społecznych, kulturowych i cywilizacyjnych, w jakich jednostki wchodzą we wzajemne kontakty. Dlatego w różnych krajach różni się bardzo między sobą zależnie od położenia geograficznego i od kulturowo zdeterminowanych zachowań ludzkich, które maja związek ze stykaniem sie jednostek z krwią i wydzielinami płciowymi” (Williams 
1995:14). Tak na przykład w Ameryce Północnej większość zakażeń (tj. 56\%) rozprzestrzenia się droga kontaktów homoseksualnych. Podobnie w Europie Wschodniej, choć tam odsetek ten wzrasta aż do 80\%. Tymczasem $\mathrm{w}$ Polsce sugerowana najczęstsza przyczyna przekazywania wirusa HIV związana jest z dożylnym podawaniem narkotyków. Te regionalne zróżnicowania również będą wpływać na budowanie obrazu chorego na AIDS w poszczególnych społeczeństwach.

\section{Wina}

Analizując czynniki wpływające na stopień stygmatyzacji osób z AIDS, koniecznym staje się także uwzględnienie potencjalnej winy chorego za swój stan. Przekonanie o odpowiedzialności zakażonych wirusem HIV prowadzi nierzadko do mniejszego okazywania współczucia, a także gotowości do udzielenia chorym pomocy i wsparcia. Może wywoływać to także negatywne zachowania i postawy u samych nosicieli HIV. W literaturze przedmiotu określa się to zjawisko mianem dewiacji wtórnej, kiedy „negatywna, stereotypowa reakcja na piętnowana chorobę lub kalectwo może utwierdzać jednostki w ich pozycji dewianta, powodować, że zaczynają one patrzeć na siebie tak samo jak ich otoczenie i odpowiednio zachowywać się" (Sokołowska 1986:214). Jednostki, które przekonywane sa o swojej niezaradności, zależności od innych, a także winie za swój stan zdrowia zaczynają zachowywać się zgodnie z panujacca na ich temat opinią, wzmacniając tym samym stereotypowy obraz chorego.

Analiza opinii Polaków z lat 1992, 1996 i 2001 wskazuje wyraźnie zależność między poziomem wykształcenia a przypisywaniem chorym winy za ich stan. Zgodnie z raportem CBOS, zdania polskiego społeczeństwa w tej sprawie sa podzielone, ale wraz z upływem czasu i poziomem wiedzy na temat AIDS, coraz więcej osób odrzuca idee winy chorego (CBOS 2001). Jednocześnie poziom tolerancji wobec osób zakażonych przez ostatnie lata nie zmienia się. 61\% Polaków uważa, że chorym powinno się pomagać. Tolerancja objawia się również przyzwoleniem na kontynuowanie pracy, także tej wymagającej kontaktów z innymi ludźmi, oraz deklaracjami gotowości pomocy i utrzymywania znajomości z osobami, u których stwierdzono AIDS. Jednocześnie jednak 8\% społeczeństwa polskiego uważa, że jednostki zakażone należy izolować, a 30\% domaga się ujawnienia informacji o nosicielstwie wirusa HIV, czyli złamaniu tajemnicy lekarskiej (TNS Polska 2012). 


\section{Przyczyny zmian}

Analiza czynników przyczyniających się do stopnia stygmatyzacji chorych na AIDS wskazuje, że budowany obraz społeczny zakażonego HIV w perspektywie historycznej ulegał przekształceniom. Związane jest to przede wszystkim $\mathrm{z}$ oswajaniem tej choroby, zwiększaniem wiedzy medycznej o sposobach jej przenoszenia, przebiegu i profilaktyce. Bardzo duże znaczenie maja kampanie rozpowszechniajace informacje o AIDS i tym samym podnoszące świadomość społeczną o tej chorobie.

W 1987 r. James W. Bunn i Thomas Netter, pracownicy Globalnego Programu ds. AIDS w Światowej Organizacji Zdrowia (WHO) w Genewie, wyszli z ideą ustanowienia Światowego Dnia AIDS, która została zrealizowana rok później. Począwszy od 1988 r., dzień 1 grudnia, obchodzony jest jako - Światowy Dzień AIDS - którego głównym celem stało się uwrażliwienie opinii społecznej na problemy epidemii AIDS. A także solidaryzowanie się z ludźmi dotkniętymi tą chorobą. Z okazji „1 grudnia” na całym świecie przeprowadzana jest kampania, majacca za zadanie zwrócenie oczu całego świata na problem HIV/ AIDS. Kampania odbywa się zawsze pod parasolowym hasłem „Zatrzymać AIDS. Dotrzymać obietnicy”. Dodatkowo, co roku, zmienia się jej szczególne przesłanie, mające na celu zwrócenie uwagi światowej społeczności na różne aspekty epidemii” (World Aids Campaign 2012) (patrz tabela 4).

$\mathrm{Na}$ szczególną uwage zasługuje zwłaszcza tematyka z początku tego wieku, która w sposób bezpośredni i jednoznaczny podejmuje problematykę stygmatyzacji i dyskryminacji osób zarażonych wirusem HIV. Jest to niezwykle ważne pamiętając o tym, że krajowe centra ds. AIDS w poszczególnych państwach rzadko w tak otwarty sposób podnosza problem praw chorych na AIDS i ich miejsca w społeczeństwie oraz zachowania zdrowych obywateli w stosunku do zakażonych. Na przykład analiza kampanii organizowanych przez Krajowe Centrum ds. AIDS w Polsce pokazuje dwukierunkowość podejmowanych działań (patrz tabela 5). Po pierwsze zwraca się uwagę na problem profilaktyki (głównie poprzez stosowanie prezerwatyw oraz wierność partnerowi). Drugi wątek dotyczy nakłaniania Polaków do przebadania się w kierunku nosicielstwa wirusa HIV i w razie potrzeby podjęcia leczenia. Niewiele natomiast pojawia się w wymienionych poniżej kampaniach informacji dotyczacych sytuacji osób zarażonych oraz problemu dyskryminacji. 
Tabela 4. Tematy światowych dni AIDS

\begin{tabular}{|l|l|}
\hline Rok & \multicolumn{1}{|c|}{ Temat } \\
\hline 1989 & Our Lives, Our World - Let's Take Care of Each Other \\
\hline 1990 & Women and AIDS \\
\hline 1991 & Sharing the Challenge \\
\hline 1992 & Community Commitment \\
\hline 1993 & „Time to Act” \\
\hline 1994 & AIDS and the Family \\
\hline 1995 & Shared Rights, Shared Responsibilities \\
\hline 1996 & One World. One Hope \\
\hline 1997 & Children Living in a World with AIDS \\
\hline 1998 & World AIDS Campaign With Young People \\
\hline 1999 & Listen, Learn, Live! World AIDS Campaign with Children \& Young People \\
\hline 2000 & Men Make a Difference \\
\hline 2001 & Men Make a Difference: „I care. Do you?” \\
\hline 2002 & Live and Let Live: Stigma and Discrimination \\
\hline 2003 & Live and Let Live: Stigma and Discrimination \\
\hline 2004 & 'Have you heard me today? Women, Girls, HIV and AIDS \\
\hline 2005 & Stop AIDS. Keep the Promise \\
\hline 2006 & Stop AIDS. Keep the Promise - Accountability \\
\hline 2007 & Stop AIDS. Keep the Promise - Leadership „Take the Lead” \\
\hline 2008 & Stop AIDS. Keep the Promise - Leadership „Lead-Empower-Deliver” \\
\hline 2009 & Stop AIDS. Keep the Promise - Universal Access and Human Right \\
\hline 2010 & Stop AIDS. Keep the Promise - Universal Access and Human Right \\
\hline
\end{tabular}

Źródło: na podstawie: World Aids Campaign (2011), http://www.worldaidscampaign.org/world-aids-day/history-of-world-aids-day

Na współczesny obraz osoby zarażonej wirusem HIV ma również wpływ sposób w jaki AIDS ukazywane jest w szeroko rozumianych działaniach związanych z promocją zdrowia. Nierzadko podkreśla się jej nieuleczalność i ogrom ludzi, którzy zostali zakażeni wirusem HIV. Budowany obraz budzi strach i przerażenie. Jedne z najbardziej kontrowersyjnych i szokujących kampanii, zaprezentowanych m.in. w Niemczech, porównywały AIDS do masowego mordercy, wykorzystując w tym celu wizerunek Hitlera i Stalina. Z podobnym przesłaniem zaprojektowano plakat we Francji przedstawiajacy trupią czaszkę zbudowana z ludzkich ciał. W końcu na uwage zasługuje także kampania przeprowadzona w USA, ukazująca sławne postacie z życia publicznego leżące w trumnach. 
Tabela 5. Hasła kampanii organizowanych przez Krajowe Centrum ds. AIDS w Polsce

\begin{tabular}{|l|l|}
\hline \multicolumn{1}{|c|}{ Rok } & \multicolumn{1}{c|}{ Hasło } \\
\hline 2000 & Nie żyj w niepewności! Wykonaj test na HIV! \\
\hline 2001 & Nie daj szansy AIDS! Bądź odpowiedzialna \\
\hline 2002 & HIV nie wybiera. Ty możesz \\
\hline 2003 & Porozmawiaj o AIDS. Przeszłość bywa groźna \\
\hline 2004 & Nie daj szansy AIDS. Zrób test na HIV \\
\hline 2005 & $\begin{array}{l}\text { ABC zapobiegania AIDS. Zdecyduj sam. Wybierz ABC zapobiegania } \\
\text { AIDS i ciesz się życiem }\end{array}$ \\
\hline 2006 & Rodzina razem przeciw AIDS \\
\hline 2007 & W życiu jak w tańcu, każdy krok ma znaczenie \\
\hline 2007 & Daj szansę swojemu dziecku. Nie daj szansy AIDS \\
\hline $2008-2009$ & Wróć bez HIV \\
\hline $2009-2010$ & Daj szansę swojemu dziecku. Nie daj szansy AIDS \\
\hline 2010 & Prezerwatywa przedłuża przyjemność \\
\hline 2010 & Wiedza ratuje życie. Zrób test na HIV \\
\hline $2011-2012$ & Zrób test na HIV! \\
\hline 2012 & FAIR PLAY. Gram fair, używam prezerwatyw \\
\hline
\end{tabular}

Źródło: Krajowe Centrum ds. AIDS (2012), http://www.aids.gov.pl/?page=kampanie\&act $=$ pl\&id=8

Warte podkreślenia jest zaangażowanie i wykorzystanie wizerunku znanych osób w promowaniu profilaktyki przeciwko AIDS. Nie jest to jednak jedyny sposób, w jaki sławne jednostki wpływaja na kreowanie obrazu zakażonych wirusem HIV. Obok szeroko pojętej edukacji społecznej na zmianę spostrzegania chorych na AIDS miały również wpływ informacje wskazujace wielu sławnych i publicznych osób, które były nosicielami wirusa HIV. Wśród nich znaleźli się znani aktorzy, piosenkarze, sportowcy, ludzie świata filmu i nauki m.in.: Kevin Peter Hall, Howard Greenfield, Anthony Perkins, Denholm Elliott, Makgatho Mandela, Eazy-E, Arthur Ashe, Freddie Mercury, Rock Hudson, Klaus Nomi, Tony Richardson, Robert Mapplethorpe, Derek Jarman, Michel Foucault, Ervin „Magic” Johnson, Władziu Valentino Liberace, Nadja Benaissa, Holly Johnson, Andy Fraser, William Jermaine Stewart, Andreas Lundstedt, Mike Beuttler, czy Greg Louganis. AIDS przestało być w opinii publicznej chorobą dotykająca zepchniętych na margines społeczny, nikomu nie znanych homoseksualistów czy narkomanów. Stało się schorzeniem, na które narażeni sa wszyscy ludzie. Jednocześnie popularność i sympatia jaką budziły sławne osoby chore na AIDS sprawiło, że z mniejszą siłą opinia publiczna obwiniała zakażonych wirusem HIV za ich stan zdrowia. 
Podsumowując, społeczny obraz chorego na AIDS ma charakter dynamiczny. Na jego zmiany wpływa przede wszystkim poziom wiedzy dotyczący dróg zakażenia, przebiegu schorzenia i profilaktyki, jak również skuteczność kampanii rozpowszechniających te informacje. Mimo ciagłej edukacji społecznej zakażeni wirusem HIV nadal nierzadko narażeni sa na ostracyzm, izolację i zepchnięcie na margines. Przyczyna takiego stanu rzeczy jest wiele czynników. Z jednej strony oddziaływuja te o charakterze medycznym związane ze specyfika choroby, a budzace duży poziom lęku społecznego. Z drugiej istnieja przyczyny społeczno-kulturowe, których zmiany wymagają czasu i systematycznego procesu edukacyjnego społeczeństw. Dopóki nie uda się opanować epidemii AIDS, należy walczyć z dyskryminacją i stygmatyzacją chorych pamiętając, że pierwotnym zagrożeniem nie jest jednak sam stygmat, a choroba, która go wywołuje.

\section{Bibliografia}

Giddens A. (2010), Socjologia, Wydawnictwo Naukowe PWN, Warszawa.

Gładysz A. (2007), Zakażenia HIV/AIDS. Poradnik dla lekarzy praktyków, Wydawnictwo Continuo, Wrocław.

Goffman E. (2005), Piętno: rozważania o zranionej tożsamości, Gdańskie Wydawnictwo Psychologiczne, Sopot.

Kmiecik-Baran K. (1995), HIV/AIDS. Alienacja i wsparcie spoteczne. Raport z badań, [w]: K. Kmiecik-Baran (red.), HIV/AIDS aspekty medyczne $i$ społeczne, Wydawnictwo Uniwersytetu Gdańskiego, Gdańsk.

Skrzypek M. (2011), Perspektywa chorego w socjologii choroby przewlektej. Ujęcia teoretyczne, ich ewolucja i recepcja, Wydawnictwo Katolickiego Uniwersytetu Lubelskiego, Lublin.

Sokołowska M. (1986), Socjologia medycyny, PZWL, Warszawa.

Sztompka P. (2002), Socjologia. Analiza społeczeństwa, Wydawnictwo Znak, Kraków.

Williams A. (1995), Ogólne wiadomości na temat epidemii zakażenia HIV [w]: K. Kmiecik-Baran (red.), HIV/AIDS aspekty medyczne i spoteczne, Wydawnictwo Uniwersytetu Gdańskiego, Sopot.

Wojciechowska J. (2011), Przyczyny dyskryminacji osób żyjacych z HIV. Nowe ujęcie teoretyczne i jego implikacje dla edukacji zdrowotnej, Wydawnictwo Uniwersytetu Gdańskiego, Gdańsk.

CBOS (2001), Społeczeństwo wobec chorych na AIDS. Komunikat z badań, Warszawa.

IBC GROUP (2011), Analiza danych uzyskanych $z$ ankiet przeprowadzonych $w$ PKD $w 2010$ r., Warszawa.

Instytut Monitorowania Mediów (2012), AIDS i HIV w Internecie, Warszawa

TNS (2012), Badanie efektywności kampanii społecznej dotyczacej profilaktyki zakażeń $H I V / A I D S$, Warszawa. 


\section{Netografia}

Krajowe Centrum ds. AIDS, aktualizacja 2012, http://www.aids.gov.pl/kampanie/2012/ UNAIDS aktualizacja 2011, http://www.unaids.org/en/

WHO, aktualizacja 2011, http://www.who.int/hiv/data/2012_epi_core_en.png

World Aids Campaign, aktualizacja 2011, http://www.worldaidscampaign.org/world-aids-day/history-of-world-aids-day/

\section{Social image of people with AIDS in the historical prospect}

In the article author describes changes which take place during the time, and which show the way people see somebody who suffers from AIDS. The first signals about new, unidentified disease appeared in the USA in 1978. Since that time AIDS has spread in the whole world. Nowadays 34 millions of people suffer from AIDS. Every year we have got 2,5 million new HIV infections. The speed, with which the virus spreads makes it one of the most dangerous threat for people's health on the whole world. In the past AIDS was identified with social groups like homosexuals, prostitutes, drug addicts. Nowadays it changes its status. Social image of people with AIDS transforms too, but it doesn't mean that people with AIDS don't suffer from stigmatization and discrimination. Author describes factors, which influence on the degree and character of people with AIDS' stigmatization. He mentions both: those with medical character, just like social and cultural factors. Finally author considers what role in those changes play campaigns against AIDS.

Key words: AIDS, HIV, stigma, discrimination. 